\title{
MORPHOLOGICAL DIVERSITY OF COTTON GERMPLASM IN DEVELOPING SELECTION METHODS TO BREED SUPERIOR COTTON VARIETY
}

\author{
Abdurrakhman*, Herwati Anik \\ Sweeteners and Fiber Crops Research Institute, Malang, Indonesia \\ *E-mail: abdurrakhman2017@gmail.com
}

\begin{abstract}
Cotton fiber supports the textile industry, folk weaving, and Indonesian paper money. The land suitable for the development of cotton should possess a dry climate. Balittas has 945 cotton germplasm accession derived from the introduction which belongs to the species Gossypium hirsutum, G. Barbadense, G. Arboreum, and G herbaceum. It is very crucial to determine germplasm characteristic. The research was carried out at KP. Karangploso, Balittas altitude of 515 masl, climate type D (moderate) Smith Ferguson, rainfall of 1500 $\mathrm{mm} /$ year, and type of soil Gleymosol Gleik / Inceptisol. The material used is 85 accessions, planted March 23, 2016. Fertilizer dosage: $97 \mathrm{~kg} \mathrm{~N}+30 \mathrm{~kg} \mathrm{P} 2 \mathrm{O} 5+30 \mathrm{~kg} \mathrm{~K} 2 \mathrm{O} / \mathrm{ha}$ and insecticides (Confidor, Furadan, Organeem. Each accession was planted $10 \mathrm{~m}$ in length, 150 $\mathrm{cm} \times 25 \mathrm{~cm}$ space. The study aims to analyze the diversity of morphological characters and cotton germplasm categorizing to ensure it can be used as a basis for selecting genetic resources in assembling new superior varieties. The results of quantitative observations at the age of 120 days exhibited high diversity. The featured characters are: budding age, flowering age, blooming age, generative branch length, number of generative branch joint, and generative branch internot length, number of vegetative branches, number of generative branches, generative branch height, canopy width, number of fruit, length of segment, weight of 40 seeded cotton. KK value were $39 \%, 59 \%, 34,24 \%, 22 \%, 24 \%, 67.22 \%, 22 \%, 28 \%$, $24 \%$ respectively. As the coefficient of diversity> $20 \%$, the assessment result exhibited significantly different character.
\end{abstract}

\section{KEY WORDS}

Cotton, identification, morphological character

The development of cotton was mainly carried out to support the textile industry, folk weaving, and Indonesian paper money. Suitable land for the development of cotton in Indonesia is widely available, especially in Central and Eastern Indonesia, which is dominated by dry land and climates. The main obstacle in developing national cotton has generally been caused by biotic factors such as pests and diseases, as well as abiotic factors in the form of water shortages (drought) causing low national productivity. Lewis (1982) states that plant productivity could be improved in two ways, namely by changing the environment (amelioration) or improving plant genotypes. Nevertheless conducting environmental improvements is very expensive and may generate negative impacts. On the other hand, improving plant genotypes is relatively cheaper, and does not cause negative impacts on the environment. This approach is conducted by assembling superior varieties. The 'Gene pool' with extensive genetic diversity is needed for building superior cotton varieties. Cotton germplasm stored in Balittas to date is 945 accessions originating from introduction through the exchange of varieties with several cotton research institutions abroad, from germplasm banks such as IRCT France, USDA America United, ICAR India, as well as from several cotton management companies. Most of the germplasm is classified as Gossypium hirsutum species, some are included in G. Barbadense, G. Arboreum, and G herbaceum.

However, until recently the collection of cotton germplasm with genetic information for the traits needed for breeders is lacking, therefore it is necessary to explore as much genetic information as possible from each existing accession through germplasm characterization and screening/evaluation activities. In the effort to improve cotton plants, a diverse 
population is needed, especially in the nature of breeding purposes. Assembly of varieties to obtain new superior varieties with desirable traits needs to be supported by germplasm with high genetic diversity (Akhtar et al. 2007). According to Bari \& Musa (1974). The availability of genetic resources with several characters that have been identified is information regarding the genetic diversity of germplasm. This aspect is crucial as it is very important to distinguish between genotypes required in the development of plant breeding programs (Bennett, 1993). According to Sumarno (2002), germplasm is a collection of genetic diversity of types of organisms. Bermawi (2005) argues that characterization is an activity to obtain morpho-agronomic characteristics or data which aims to distinguish phenotype from each accession. The characterization uses instructions from The International Union For The Protection Of New Varieties Of Plants (UPOV 2002). The following step is determining genetic diversity by grouping germplasm. The grouping method is an indispensable step in the utilization of the germplasm collection (Bozokalfa et al. 2009; Lule et al. 2012). The degree of variation in the genetic material will determine genetic diversity. Grouping germplasm collections is a strategy in the effort to utilize germplasm collections (Bozokalfa et al. 2009; Lule et al. 2012). The success of crop selection in breeding depends on genetic variation from existing germplasm accessions (Akhtar et al. 2007). Germplasm collections need to be characterized to ensure their properties are known as genetic information in the variety assembly program. This study aims to analyze the diversity of morphological characters and grouping of cotton germplasm of the Balittas collection to ensure it could be utilized as a basis for selecting genetic resources in the assembly of new superior varieties.

\section{MATERIALS AND METHODS OF RESEARCH}

The research activities were carried out at KP. Karangploso, Balittas with an altitude of 515 masl possessing type $D$ (moderate) climate Smith Ferguson, rainfall $1500 \mathrm{~mm} /$ year, and type of Gleymosol Gleik / Inceptisol soil, from January to December 2016. Research material used were 100 cotton germplasm accessions (Table 1), planted on March 23, 2016. The fertilizer dosage used is $97 \mathrm{~kg} \mathrm{~N}+30 \mathrm{~kg} \mathrm{P} 2 \mathrm{O} 5+30 \mathrm{~kg} \mathrm{~K} 2 \mathrm{O} / \mathrm{ha}$. Insecticides Confidor, Furadan, Organeem. Each accession was planted in one row for $10 \mathrm{~m}$. Planting distance of $150 \mathrm{~cm} \times 25 \mathrm{~cm}$, one plant per hole. Fertilization was done twice, 1/3 dose of $\mathrm{N}$ and all doses of $\mathrm{P} 2 \mathrm{O} 5$ and $\mathrm{K} 2 \mathrm{O}$ at the time of planting, and 2/3 doses of $\mathrm{N}$ on 30 days after planting. Observation of morphological characters referred to the cotton descriptor list from International Union for the Protection of New Varieties of Plants (UPOV 2001).

The results of correlation analysis exhibited a positive or negative correlation between (1) plant height with canopy width, flowering age, and weight of 100 fruits (2) number of epidermis with flowering age (3) budding age with number of fruits and fiber length (4) flowering age with plant height, budding age, and fiber length (5) number of plant/ fruit with weight of 100 fruits (6) weight of 100 fruits with plant height, flowering age, and number of fruit / plant. It indicates that the characters observed above are related to each other. The descriptive Statistics quantitative character of cotton germplasm referred to (Descriptor list) from the International Union For The Protection of New Varieties of Plants (UPOV 2012), as presented in (Table. 3).

Method of germplasm accession grouping utilized cluster analysis with Euclidian distance and average linkage method (Suhartini \& Sutoro 2007; Setyowati et al. 2009; Furat \& Uzun 2010). The variables used in the grouping are variables that are mutually independent. In the initial phase, quantitative character data were analyzed using the Pearson correlation coefficient. If there is a correlation, the observed variables are transformed into the main component variables. The main component analysis was done after the quantitative data is standardized by dividing each variable with its standard deviation, therefore it is within the commensurate range due to different data units (Joliffe 2002; Tresniawati \& Randriani 2008). The results of the main component analysis were followed by cluster fingerprint analysis. Data analysis was carried out using Minitab 15 software. 
The diversity of cotton germplasm based on morphological characters could be predicted through the value of the Diversity Coefficient (CV) of each parameter observed. Nilasari et al. 2013 and Hadi et al. 2014), argues that to estimate the level of difference in the observed germplasm population, CV Value could be utilized. (Table 3 ). The results of the quantitative morphological characterization exhibited a high diversity in the number of epidermises on the leaves, flowering age, plant height, and canopy width.

Table 1 - 100 cotton germplasm accessions Research material

\begin{tabular}{|c|c|c|c|c|c|c|c|}
\hline NO. & Accession/Var & Population & Origin & NO. & Accession/Var & Population & Origin \\
\hline 1 & Kanesia 8 & Var & Var & 51 & KI 123 & USA & AMERICA \\
\hline 2 & Kanesia 10 & Var & Var & 52 & KI 124 & USA & AMERICA \\
\hline 3 & Kanesia 14 & Var & Var & 53 & $\mathrm{KI} 240$ & USA & AMERICA \\
\hline 4 & Kanesia 15 & Var & Var & 54 & KI 845 & BRAZIL & AMERICA \\
\hline 5 & Kanesia 16 & VAr & Var & 55 & KI 846 & BRAZIL & AMERICA \\
\hline 6 & Kanesia 20 & Var & Var & 56 & KI 847 & BRAZIL & AMERICA \\
\hline 7 & $\mathrm{KI} 2$ & USA & AMERICA & 57 & KI 848 & BRAZIL & AMERICA \\
\hline 8 & $\mathrm{KI} 15$ & USA & AMERICA & 58 & KI 849 & BRAZIL & AMERICA \\
\hline 9 & $\mathrm{KI} 17$ & USA & AMERICA & 59 & $\mathrm{KI} 850$ & BRAZIL & AMERICA \\
\hline 10 & $\mathrm{KI} 19$ & USA & AMERICA & 60 & KI 851 & BRAZIL & AMERICA \\
\hline 11 & $\mathrm{KI} 20$ & USA & AMERICA & 61 & $\mathrm{KI} 409$ & Nicaragua & AMERICA \\
\hline 12 & $\mathrm{KI} 23$ & USA & AMERICA & 62 & $\mathrm{KI} 30$ & Yugoslavia & EUROPE \\
\hline 13 & $\mathrm{KI} 74$ & USA & AMERICA & 63 & $\mathrm{KI} 40$ & Yugoslavia & EUROPE \\
\hline 14 & $\mathrm{KI} 75$ & USA & AMERICA & 64 & KI 51 & Yugoslavia & EUROPE \\
\hline 15 & $\mathrm{KI} 76$ & USA & AMERICA & 65 & $\mathrm{KI} 38$ & Bulgaria & EUROPE \\
\hline 16 & KI 77 & USA & AMERICA & 66 & $\mathrm{KI} 46$ & Bulgaria & EUROPE \\
\hline 17 & $\mathrm{KI} 82$ & USA & AMERICA & 67 & $\mathrm{KI} 44$ & USSR & EUROPE \\
\hline 18 & $\mathrm{KI} 85$ & USA & AMERICA & 68 & $\mathrm{KI} 448$ & FRENCH & EUROPE \\
\hline 19 & $\mathrm{KI} 86$ & USA & AMERICA & 69 & KI 951 & INDONESIA & ASIA \\
\hline 20 & $\mathrm{KI} 88$ & USA & AMERICA & 70 & KI 952 & INDONESIA & ASIA \\
\hline 21 & KI 89 & USA & AMERICA & 71 & KI 339 & PHILIPINA & ASIA \\
\hline 22 & $\mathrm{KI} 90$ & USA & AMERICA & 72 & $\mathrm{KI} 47$ & INDIA & ASIA \\
\hline 23 & KI 92 & USA & AMERICA & 73 & KI 151 & INDIA & ASIA \\
\hline 24 & KI 94 & USA & AMERICA & 74 & KI 320 & INDIA & ASIA \\
\hline 25 & KI 95 & USA & AMERICA & 75 & KI 351 & INDIA & ASIA \\
\hline 26 & $\mathrm{KI} 96$ & USA & AMERICA & 76 & $\mathrm{KI} 48$ & PAKISTAN & ASIA \\
\hline 27 & KI 97 & USA & AMERICA & 77 & KI 58 & PAKISTAN & ASIA \\
\hline 28 & KI 98 & USA & AMERICA & 78 & KI 62 & CHINA & ASIA \\
\hline 29 & KI 99 & USA & AMERICA & 79 & KI 688 & CHINA & ASIA \\
\hline 30 & $\mathrm{KI} 102$ & USA & AMERICA & 80 & KI 689 & CHINA & ASIA \\
\hline 31 & KI 103 & USA & AMERICA & 81 & KI 691 & CHINA & ASIA \\
\hline 32 & KI 104 & USA & AMERICA & 82 & KI 693 & CHINA & ASIA \\
\hline 33 & KI 105 & USA & AMERICA & 83 & $\mathrm{KI} 36$ & CAMERON & AFRICA \\
\hline 34 & KI 106 & USA & AMERICA & 84 & KI 39 & UGANDA & AFRICA \\
\hline 35 & KI 107 & USA & AMERICA & 85 & $\mathrm{KI} 43$ & UGANDA & AFRICA \\
\hline 36 & KI 108 & USA & AMERICA & 86 & $\mathrm{KI} 45$ & UGANDA & AFRICA \\
\hline 37 & KI 109 & USA & AMERICA & 87 & KI 135 & USA & AFRICA \\
\hline 38 & KI 110 & USA & AMERICA & 88 & KI 168 & USA & AFRICA \\
\hline 39 & KI 111 & USA & AMERICA & 89 & KI 268 & USA & AFRICA \\
\hline 40 & $\mathrm{KI} 112$ & USA & AMERICA & 90 & KI 289 & EGYPT & AFRICA \\
\hline 41 & KI 113 & USA & AMERICA & 91 & KI 711 & EGYPT & AFRICA \\
\hline 42 & KI 114 & USA & AMERICA & 92 & KI 364 & NIGERIA & AFRICA \\
\hline 43 & KI 115 & USA & AMERICA & 93 & $\mathrm{KI} 453$ & NIGERIA & AFRICA \\
\hline 44 & $\mathrm{KI} 116$ & USA & AMERICA & 94 & KI 502 & AUSTRALIA & AUSTRALIA \\
\hline 45 & KI 117 & USA & AMERICA & 95 & KI 509 & AUSTRALIA & AUSTRALIA \\
\hline 46 & KI 118 & USA & AMERICA & 96 & KI 510 & AUSTRALIA & AUSTRALIA \\
\hline 47 & KI 119 & USA & AMERICA & 97 & KI 564 & AUSTRALIA & AUSTRALIA \\
\hline 48 & KI 120 & USA & AMERICA & 98 & KI 569 & AUSTRALIA & AUSTRALIA \\
\hline 49 & KI 121 & USA & AMERICA & 99 & KI 629 & AUSTRALIA & AUSTRALIA \\
\hline 50 & KI 122 & USA & AMERICA & 100 & KI 633 & AUSTRALIA & AUSTRALIA \\
\hline
\end{tabular}

The results analyzed by the correlation of quantitative observations are presented in (Table 2). 
Table 2 - Correlations between quantitative variables

\begin{tabular}{|c|c|c|c|c|c|c|c|c|c|}
\hline \multicolumn{2}{|r|}{$\mathrm{n} / \mathrm{n}$} & TT & LK & $\mathrm{JB}$ & UK & UB & $\mathrm{JBH}$ & B100 & PS \\
\hline \multirow[t]{3}{*}{ TT } & Pearson Correlation & 1 & $.523^{\pi / 1}$ & 0.168 & 0.013 & .341 & -0.043 & -.269 & -0.132 \\
\hline & Sig. (2-tailed) & & 0 & 0.096 & 0.902 & 0.001 & 0.672 & 0.007 & 0.189 \\
\hline & $\mathrm{N}$ & 100 & 100 & 100 & 100 & 100 & 100 & 100 & 100 \\
\hline \multirow[t]{3}{*}{ LK } & Pearson Correlation & .523 & 1 & -0.075 & 0.074 & 0.146 & 0.042 & -0.052 & 0.087 \\
\hline & Sig. (2-tailed) & 0 & & 0.458 & 0.467 & 0.147 & 0.675 & 0.61 & 0.388 \\
\hline & $\mathrm{N}$ & 100 & 100 & 100 & 100 & 100 & 100 & 100 & 100 \\
\hline \multirow[t]{3}{*}{$\mathrm{JB}$} & Pearson Correlation & 0.168 & -0.075 & 1 & $.277^{*}$ & 0.039 & 0.009 & -0.1 & -0.048 \\
\hline & Sig. (2-tailed) & 0.096 & 0.458 & & 0.005 & 0.697 & 0.927 & 0.322 & 0.638 \\
\hline & $\mathrm{N}$ & 100 & 100 & 100 & 100 & 100 & 100 & 100 & 100 \\
\hline \multirow[t]{3}{*}{ UK } & Pearson Correlation & 0.013 & 0.074 & .277 & 1 & .296 & 0.087 & -0.047 & .239 \\
\hline & Sig. (2-tailed) & 0.902 & 0.467 & 0.005 & & 0.003 & 0.39 & 0.643 & 0.017 \\
\hline & $\mathrm{N}$ & 100 & 100 & 100 & 100 & 100 & 100 & 100 & 100 \\
\hline \multirow[t]{3}{*}{ UB } & Pearson Correlation & $.341^{\prime \prime}$ & 0.146 & 0.039 & .296 & 1 & 0.007 & -.380 & 0.165 \\
\hline & Sig. (2-tailed) & 0.001 & 0.147 & 0.697 & 0.003 & & 0.946 & 0 & 0.101 \\
\hline & $\mathrm{N}$ & 100 & 100 & 100 & 100 & 100 & 100 & 100 & 100 \\
\hline \multirow[t]{3}{*}{ JBH } & Pearson Correlation & -0.043 & 0.042 & 0.009 & 0.087 & 0.007 & 1 & -.236 & 0.131 \\
\hline & Sig. (2-tailed) & 0.672 & 0.675 & 0.927 & 0.39 & 0.946 & & 0.018 & 0.193 \\
\hline & $\mathrm{N}$ & 100 & 100 & 100 & 100 & 100 & 100 & 100 & 100 \\
\hline \multirow[t]{3}{*}{ B100 } & Pearson Correlation & $-.269^{* *}$ & -0.052 & -0.1 & -0.047 & $-.380^{* *}$ & $-.236^{*}$ & 1 & -0.105 \\
\hline & Sig. (2-tailed) & 0.007 & 0.61 & 0.322 & 0.643 & 0 & 0.018 & & 0.297 \\
\hline & $\mathrm{N}$ & 100 & 100 & 100 & 100 & 100 & 100 & 100 & 100 \\
\hline \multirow[t]{3}{*}{ PS } & Pearson Correlation & -0.132 & 0.087 & -0.048 & $.239^{\circ}$ & 0.165 & 0.131 & -0.105 & 1 \\
\hline & Sig. (2-tailed) & 0.189 & 0.388 & 0.638 & 0.017 & 0.101 & 0.193 & 0.297 & \\
\hline & $\mathrm{N}$ & 100 & 100 & 100 & 100 & 100 & 100 & 100 & 100 \\
\hline
\end{tabular}

** Correlation is significant at the 0.01 level (2-tailed).

* Correlation is significant at the 0.05 level (2-tailed).

Notes:

TT: Plant Height (cm); UB: Flowering age (hr); LK: Canopy Width; JBH: Fruit/plant; JB: Number of epidermis $\left(\mathrm{mm}^{2}\right)$; B100: Weight of 100 fruits (gram); UK:Flower bud age(day); PS: \% fiber.

CV values of the characters were $65 \%, 59 \%, 42 \%$, and $45 \%$ respectively. The coefficient of diversity was $20 \%$ Alnopri \& Hermiati (1992). High diversity values indicate that these characters have a wide variety. This provides an opportunity for breeders to make a selection to choose superior accession. The budding age, number of fruits/plants, weight of 100 fruits and percentage of fiber with CV values of $17 \%, 14 \%, 5.3 \%$, and $9.4 \%$. These possess low diversity coefficient as the CV value is below $20 \%$.

Table 3 - Descriptive Statistics of quantitative characters of cotton germplasm

\begin{tabular}{|c|c|c|c|c|c|c|c|c|c|}
\hline \multirow{2}{*}{$\mathrm{n} / \mathrm{n}$} & $\mathrm{N}$ & Range & Minimum & Maximum & \multirow{2}{*}{ Mean } & \multirow{2}{*}{ Std. Error } & $\begin{array}{c}\text { Std. } \\
\text { Deviation }\end{array}$ & Variance & CV (\%) \\
\cline { 2 - 3 } & Statistic & Statistic & Statistic & Statistic & Statistic & & Statistic & Statistic & Statistic \\
\hline TT & 100 & 118.8 & 86.2 & 205 & $1.42 \mathrm{E}+02$ & 2.57794 & 25.77937 & 664.576 & 65 \\
\hline LK & 100 & 161.5 & 12.5 & 174 & $1.14 \mathrm{E}+02$ & 2.36365 & 23.63647 & 558.683 & 17 \\
\hline JB & 100 & 296 & 0 & 296 & 40.376 & 6.21773 & 62.17734 & $3.87 \mathrm{E}+03$ & 59 \\
\hline UK & 100 & 19 & 40 & 59 & 44.5 & 0.26419 & 2.64193 & 6.98 & 42 \\
\hline UB & 100 & 29 & 51 & 80 & 55.36 & 0.38938 & 3.89384 & 15.162 & 45 \\
\hline JBH & 100 & 355.6 & 10.4 & 366 & 25.931 & 3.48925 & 34.89251 & $1.22 \mathrm{E}+03$ & 14 \\
\hline B100 & 100 & 468 & 294 & 762 & $5.40 \mathrm{E}+02$ & 10.18266 & 101.82656 & $1.04 \mathrm{E}+04$ & 5.3 \\
\hline PS & 100 & 37.76 & 16.67 & 54.42 & 37.7625 & 0.40043 & 4.00431 & 16.034 & 9.4 \\
\hline $\begin{array}{l}\text { Valid N } \\
\text { (listwise) }\end{array}$ & 100 \\
\hline
\end{tabular}

The density of epidermis is often used by plant breeders to control the attack of sucker piercing insects. Amrasca biguttula (Empoasca sp.) is the main cotton plant pest in Indonesia, which is very detrimental because it can attack cotton plants starting from young plants to old plants. Great attacks occur if the environmental conditions are dry due to lack of rain. These pests attack the plant by sucking the leaf liquid, the plants attacked the leaves 
become curly and curved downward. In heavy attacks the leaves are red-brown, dry, then the expression is influenced by the genes $\mathrm{H}_{2}, \mathrm{H} 3, \mathrm{H}_{4}$, and $\mathrm{H}_{5}$, (Hendrizzi et al., 1984). The density of epidermis on Ballitas cotton germplasm varied from 0 - 587 trichomes per $25 \mathrm{~mm}^{2}$. The density of epidermis was calculated using the Robinson method, et al., (1980), $5 \mathrm{~mm} \times 5$ $\mathrm{mm}$ square was carved on the lower leaf lamina, the number of the epidermises (trichomes) was calculated based the square. The trichome number category per square centimeter $\left(\mathrm{cm}^{2}\right)$ according to Kartono (1991), is: $<121=$ no epidermis; $121-240=$ small number of epidermis; $241-360=$ medium epidermis; $361-480=$ large number of epidermis; $>480=$ huge number of epidermis. Cotton varieties with epidermisless properties possess high tannin and terpene content. It is capable to reduce Helicoverpa armigera pest attacks up to $50 \%$ (Benedict et al., 1992). The diversity of epidermis from 100 accessions observed exhibited a diversity of CV $59 \%$.

Table 4 - Qualitative characteristics of cotton germplasm

\begin{tabular}{|c|c|c|}
\hline \multicolumn{2}{|c|}{ Qualitative Characters } & \multirow{2}{*}{$\begin{array}{l}\text { Percentage (\%) } \\
2 \\
98\end{array}$} \\
\hline 1. Flower position & $\begin{array}{l}\text { Clustered } \\
\text { Not Clustered }\end{array}$ & \\
\hline 2. Leaf color & $\begin{array}{l}\text { Green } \\
\text { Light Green } \\
\text { Green } \\
\text { Dark Green } \\
\text { Reddish Purple }\end{array}$ & $\begin{array}{l}97 \\
0 \\
0 \\
1 \\
2\end{array}$ \\
\hline 3. Leaf shape & $\begin{array}{l}\text { Palmate } \\
\text { Normal } \\
\text { Twisted Normal } \\
\text { Palmate Normal } \\
\text { Twisted }\end{array}$ & $\begin{array}{l}8 \\
84 \\
5 \\
2 \\
1 \\
\end{array}$ \\
\hline 4. Nectar & $\begin{array}{l}\text { Exist } \\
\text { Nonexistent } \\
\text { Exist/Nonexistent }\end{array}$ & $\begin{array}{l}90 \\
9 \\
1 \\
\end{array}$ \\
\hline 5. Crown color & $\begin{array}{l}\text { Beige } \\
\text { Yellow } \\
\text { Beige/Yellow } \\
\text { Yellow/Purple }\end{array}$ & $\begin{array}{l}87 \\
4 \\
1 \\
8 \\
\end{array}$ \\
\hline 6. Spots on the flower crown & $\begin{array}{l}\text { Exist } \\
\text { Non Existent }\end{array}$ & $\begin{array}{l}4 \\
96\end{array}$ \\
\hline 7. Pollen colour & $\begin{array}{l}\text { Beige } \\
\text { Yellow Beige } \\
\text { Purple Beige } \\
\text { Yellow } \\
\text { Purple Yellow }\end{array}$ & $\begin{array}{l}72 \\
1 \\
0 \\
27 \\
0 \\
\end{array}$ \\
\hline 8. Pistil Position & $\begin{array}{l}\text { Above } \\
\text { Parallel }\end{array}$ & $\begin{array}{l}76 \\
24\end{array}$ \\
\hline 9. Petal shape & $\begin{array}{l}\text { Twisted } \\
\text { Normal }\end{array}$ & $\begin{array}{l}1 \\
99\end{array}$ \\
\hline 10. stem color & $\begin{array}{l}\text { Reddish Green } \\
\text { Dark Green } \\
\text { Purplish Red }\end{array}$ & $\begin{array}{l}95 \\
2 \\
3\end{array}$ \\
\hline 11. plant shape & $\begin{array}{l}\text { Compact } \\
\text { Cylindric } \\
\text { Prostrate }\end{array}$ & $\begin{array}{l}35 \\
5 \\
60\end{array}$ \\
\hline 12. fruit shape sharpness & $\begin{array}{l}\text { Pointy } \\
\text { Spiky } \\
\text { Sharp } \\
\text { Blunt }\end{array}$ & $\begin{array}{l}5 \\
92 \\
1 \\
3\end{array}$ \\
\hline 13.Fruit skin texture & $\begin{array}{l}\text { Smooth } \\
\text { Medium } \\
\text { Coarse }\end{array}$ & $\begin{array}{l}3 \\
82 \\
15 \\
\end{array}$ \\
\hline 14.Fiber color & $\begin{array}{l}\text { White } \\
\text { Light Brown } \\
\text { Light Green } \\
\text { Brown }\end{array}$ & $\begin{array}{l}96 \\
2 \\
1 \\
1\end{array}$ \\
\hline
\end{tabular}


The density of the epidermis is one of the characteristics of a variety of options as accessions resistant to sucker piercing pests, which are the main cotton plant pest in Indonesia. Great attacks occur if the environmental conditions are dry due to lack of rain. Hendrizzi et al., (1984), suggested that the Amasca biguttula attacks plants by sucking in leaf fluid. Attacked plants leaves become curly and curved downward. In heavy attacks the leaves are red-brown, dry, then their expression is influenced by genes $\mathrm{H}_{2}, \mathrm{H}_{3}, \mathrm{H}_{4}$, and $\mathrm{H}_{5}$. The density of epidermis in Ballitas cotton germplasm varies from $0-587$ trichomes per 25 $\mathrm{mm}^{2}$. The density of epidermis was calculated using the Robinson, et al., (1980) method, a square of $5 \mathrm{~mm} \times 5 \mathrm{~mm}$ was carved in the lower leaf lamina, the number of the epidermises (trichomes) was calculated based on existing epidermis in the square.

Germplasm plasma is observed as a qualitative character, carried out if the conditions have met the requirements in accordance with the reference (Suratman \& Setyawan, 2000). The results of the observations exhibited a diversity of all characters observed (Table 4). The observation of the character of the 100 accessions observed: $98 \%$ is not clustered and $2 \%$ are clustered, meaning that the diversity is very low. The color characteristics of the leaf diversity are very low, such as green $(97 \%)$, light green $(0 \%)$, green $(0 \%)$, dark green $(1 \%)$, and reddish purple $(2 \%)$. Plant shape characters are compact $(35 \%)$, cylindrical $(5 \%)$, and Prostrate $(60 \%)$.

From the observation of the character of cotton, leaf shape varies, namely: palmate $(8 \%)$, normal $(84 \%)$, normal twisting (5\%), normal palmate $(2 \%)$, and twisting $(1 \%)$. exhibited that the diversity is quite high. Leaf shape is an important character in the classification of varieties. Wilson and George (1982), suggested that the nature of the okra leaf leaves can reduce the egg deposit of Helioverpa armigera, increase resistance to Peptinopora gossypiella, and reduce fruit rot disease. On average the cotton on the leaves has the nectar glands. Out of the 100 accessions observed, only one accession which nectar existence is unclear, 99\% exist and 9\% of accessions nonexistent. Wilson (1976), suggested that the nectar is one of the important properties for resistance to flower buds and fruit piercer. The color of the flower crowns on 100 accessions was varied: beige $(57 \%)$, yellow $(3 \%)$, yellow/beige $(1 \%)$ and yellow/purple (8\%). The crown color of the Gossypium tetraploid species is controlled by the duplication of $\mathrm{Y} 1$ and $\mathrm{Y} 2$ Hutchison and Silow genes, 1939. In Kohel and Lewis (1984), it is suggested that yellow is all allotetraploid except yellow in G. From this gene $\mathrm{Y} 1$ is controlled by $\mathrm{Y} 2$ gene according to Stephens (1954 b In Kohel and Lewis, 1984). Y1 gene in sub-genomics possesses chromosome $18 \mathrm{D} Y 2$ gene. The genome is D. The yellow flower crown is usually found in G. barbadense, (Endrizzi, 1975 In Kohel and Lewis, 1984), but often found in Pima cotton (Turcottte and Feaster, 1963 In Kohel and Lewis, 1984). The beige-colored flower crown is found in $\mathrm{G}$. hirsutum cultivars which are controlled by the y1y1y2y2 gene but also found in yellow flower crowns on wild relatives. The spots on the flower crown possess low diversity. The spotted ones were $(5 \%)$ and no spot $(95 \%)$. The color of pollen is quite varied which includes: beige $(72 \%)$, yellow beige $(1 \%)$, purple beige $(0 \%)$, yellow $(27 \%)$, and purple yellow (0\%). Harlan (1929) In Kohel and Lewis (1984), suggested that pollen color is controlled by a pair of $P$ and $p$ genes. Whereas the yellow color is dominant in beige. The position of the pistil is above $(76 \%)$ and parallel $(24 \%)$. The petal shape diversity is very low: twisted $(1 \%)$ and normal $(99 \%)$. The stem color character diversity is very low: reddish green (95\%), dark green $(2 \%)$ and purplish red $(3 \%)$. Stephenss, (1974 a), suggested that the red color of the stem was caused by the presence of anthocyanin substances which pigmentation was expressed on the tissues of the leaf sertan on the base of the flower crown which usually occurs in cotton breedd in Asia. The sharpness of the fruit shape, spiked fruit reached $(92 \%)$, pointy fruit $(5 \%)$, sharp $(1 \%)$ and blunt $(3 \%)$. The fruit skin coarseness exhibited: smooth $(3 \%)$, medium $(82 \%)$ and coarse $(15 \%)$. The variation of fiber color character is also very low, the dominant color is white which reaches $96 \%$, light brown $(2 \%)$, light green $(1 \%)$ and brown $1 \%$. Fruit skin texture diversity is smooth (3\%), medium ( $82 \%)$, and coarse $(15 \%)$.

The genetic relationship is an effort to find out the relationship between genotypes in the accession of cotton plants. Furthermore, based on the genetic similarities the character will be classified, by describing the level of genetic variability, used for genetic analysis 
based on morphological characters. Prior to carrying out a cluster analysis for germplasm grouping, it is important to determine whether the variables observed are mutually independent. Maji \& Shaibu (2012), suggests that if there is a correlation between the variables observed, it is necessary to analyze the main components first, before conducting a cluster analysis. The results of the correlation analysis exhibited no real correlation between the characters observed. Subsequent cluster analysis was carried out using characters that contributed to the diversity of the first six main components because the proportion of diversity reached more than $80 \%$ and eigenvalues $>1$. Joliffe (1967) gave the limitation that cluster analysis was carried out using characters the proportion of diversity $>80 \%$ and eigenvalues $>1$. The results of the cluster analysis exhibited that the Balittas cotton germplasm collection was divided into $\mathrm{VI}$ levels of similarity that had a relatively high diversity. At the level of similarity I of germplasm is divided into 3 major groups, at the level of similarity II is divided into 4 groups, in similarity III is divided into 5 major groups, in similarity IV is divided into 2 major groups, in similarity $\mathrm{V}$ is divided into 2 major groups and in similarity $\mathrm{VI}$ is divided into 6 large groups (Figure 1). Grouping based on the country of origin of germplasm consists of Indonesian commercial varieties, United States of America (USA), South America, Europe, Asia, Africa, and Australia with a diversity of $84.90 \%$. Categorized germplasm diversity can be used as an important source of information to assess potential accession. Accession from different groups possess significantly different character, therefore a high diversity of morphological characters in the managed population provides wider opportunities for the improvement of plant varieties. To obtain information on the diversity of crucial agronomic traits, which can later be used as elders selected in cultivation programs. Accessions possessing a genetic distance from different groups can be selected, information on the diversity of morphological characters also opens up opportunities for improved varieties with resistance to biotic and abiotic stresses. Cluster analysis method could be used to determine the characters that contribute to population diversity (Khodadadi et al. 2011). Tresniawati \& Randriani (2008), stated that germplasm grouping can describe genetic relationships between accessions. This may provide information regarding character traits from each accession group formed.

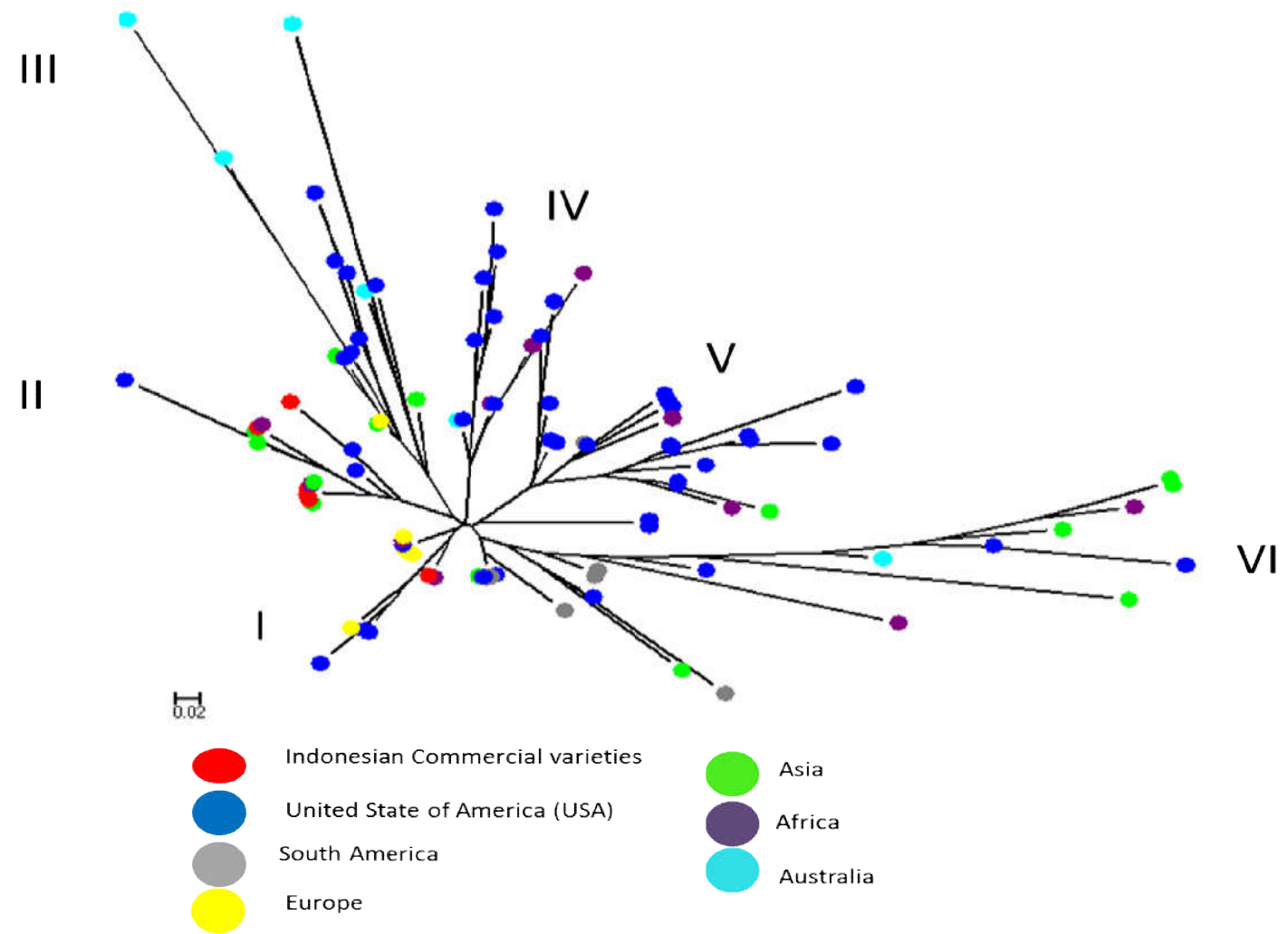

Figure 1 - Dendrogram average linkage, euclidian distance 


\section{CONCLUSION}

The results of the qualitative morphological characterization exhibited diverse characters: low (flower position, spots on the flower crown, pollen color, fiber color, and petal shape), medium (nectar, crown color, stem color, and fruit shape sharpness) and height (position of pistil, plant shape and fruit skin coarseness).

The results of the quantitative morphological characterization exhibited high diversity with CV values: number of leaves (65\%) flowering age $(59 \%)$, plant height $(42 \%)$, and canopy width $(45 \%)$.

The results of the cluster analysis indicate that the Balittas germplasm collection is divided into 6 large groups of similarity level and possess relatively high diversity. At the level of similarity I of germplasm is divided into 3 major groups, at the level of similarity II is divided into 4 groups, in similarity III is divided into 5 major groups, in similarity IV is divided into 2 major groups, in similarity $\mathrm{V}$ is divided into 2 major groups, and in the similarity $\mathrm{VI}$ is divided into 6 large groups (Figure 1). Based on country of origin grouping, germplasm consists of Indonesian commercial varieties, United State of America (USA), South America, Europe, Asia, Africa, and Australia with a diversity value of $88.90 \%$.

\section{REFERENCES}

1. Akhtar, MS, Oki, Y, Adachi, T \& Khan MHR. 2007. Analyses of the genetic parameters: variability, Heritability, Genetic Advance, Relationship of Yield and Yield Contributing Characters) for some plant traits among Brassica cultivars under phosphorus-starved environmental cues. Journal of the Faculty of Environmental Science and Technology, 12:91-98.

2. Alnopri, R.S.S. \& Hermiati, N. 1992. Kriteria seleksi berdasarkan sifat morfologi tanaman kopi robusta. Zuriat 3:18-22.

3. Bozokalfa, MK, Esiyok, D \& Turhan, K. 2009, Patterns of phenotypic variation in a germplasm collection of pepper (Capsicum annuum L.) from Turkey. Spanish Journal of Agricultural Research, 7(1):83-95.

4. Bari, S \& Musa. 1974. Pengantar Pemuliaan Tanaman , Institut Pertanian Bogor. 60p

5. Bermawi, N. 2005. Karakterisasi Plasma Nutfah Tanaman. In Luntungan, H.T., Karmawati, E., Hartati, R.S. (Eds). Buku Pedoman Pengelolaan Plasma Nutfah Perkebunan. Pusat Penelitian dan Pengembangan Perkebunan, Bogor, Indonesia

6. Sumarno. 2002. Penggunaan bioteknologi dalam pemanfaatan dan pelestarian plasma nutfah tumbuhan untuk perakitan varietas unggul. National Seminar on "Pemanfaatan dan Pelestarian Plasma Nutfah". Pusat Penelitian Biologi IPB \& Komisi Nasional Plasma Nutfah, Indonesia.

7. Suratman, P.D. \& Setyawan, A.D. 2000. Analisis keragaman genus Ipomea berdasarkan karakter morfologi, Biodiversitas, 1(2):72-79.

8. Suhartini, T \& Sutoro. 2007, Pengelompokan plasma nutfah spesies padi liar (Oryza spp.) berdasarkan peubah kuantitatif tanaman. Berita Biologi, 8(6):445-453.

9. Setyowati, M., Hanarida, I., \& Sutoro. 2009. Pengelompokan plasma nutfah gandum (Triticumaestivum) berdasarkan karakter kuantitatif tanaman. Buletin Plasma Nutfah, 15(1):32-37.

10. Lewis, C.F. 1982. Genetic Engineering for Improving Environmental Resiliency in Crop Species. In Cristianson and Lewis. Breeding Plant for Less Favorable Environments. Interscience Publication, 435-439.

11. Lule, D., Tesfaye, K., Fetene, M., \& de Villiers S. 2012. Multivariate analysis for quantitative traits in finger millet (Eleusine coracana subsp. coracana) population collected from Eastern and Southeastern Africa: detection patterns of genetic diversity. International Journal of Agricultural Research, 7(6):303-314.

12. Furat, S \& Uzun, B. 2010. The use of agro-morphological characters for the assessment of genetic diversity in sesame (Sesame indicum L.). Plant Omics Journal, 3(3):85-91. 
13. Joliffe, I.T. 2002. Principal Component Analysis Second Edition, Springer-Verlag Inc, New York, 518p.

14. Nilasari, A.N., Heddy, J.B.S., \& Wardiyati T. 2013, Identifikasi keragaman morfologi daun mangga (Mangifera indica L.) pada tanaman hasil persilangan antara varietas Arumanis 143 dengan Podang Urang umur 2 tahun. Jurnal Produksi Tanaman, 1(1):61-69.

15. Hendrizzi, E.L. Turcotte \& R.J. Kohel. 1984. Quantitative genetics cytology and cytogenetics In. R.J. Kohel and C.F. Lewis (Eds). Cotton ASA. Inc. CSSA In. Publisher Madizon. Agronomy Series N0 24. Pp 81-129. Monosomic analysis of 23 mutant loci in cotton. In R.J. Kohel and C.F. Lewis (Eds.). Cotton ASA. Inc. CSSA Ins. Publisher Madison. Agronomy Series N. 24. Pp. $81-129$.

16. Kohel, R.J. and Lewis. 1984. Growth analysis of cotton with differing maturities. Agron. J. 70: $31-34$.

17. Maji, A.T. \& Shaibu, A.A. 2012. Application of principal component analysis of rice germplasm characterization and evaluation, Journal of Plant breeding and Crop Science, 4(6):87-93.

18. Khodadadi, M, Fotokian, MH \&Miransari, M 2011, Genetic diversity of wheat (Triticum aesticum L.) genotypes based on cluster and principal component analyses for breeding strategies, Australian Journal of Crop Science, 5(1):17-24.

19. Tresniawati, C \& Randriani, E. 2008. Uji kekerabatan koleksi plasma nutfah macadamia(Macadamia integrifolia Maiden \& Betche) di Kebun Percobaan Manoko, Lembang, Jawa Barat. Buletin Ristri, 1(1): 25-31. 